\title{
Strategy of the Primary and Secondary Education Council of Muhammadiyah Regional Leaders in Maintaining the Quality of Education during the COVID-19 Pandemic Period in Sinjai Regency
}

\author{
Sukarno Hatta ${ }^{1}$, Supratman Tahir $^{2}$, Baharuddin ${ }^{3}$ \\ ${ }^{1,2,3}$ Universitas Muhammadiyah Sinjai \\ Email: sukarnohatta8885@gmail.com
}

\begin{abstract}
Education is a medium or tool to produce human resources into something of higher quality. The purpose of this research itself is to find out how the steps or strategies taken by the Assembly in maintaining the quality of education for students amid the outbreak of the virus and triggering the birth of several rules that suddenly change all old habits. As a benchmark used by researchers by looking at indicators as conveyed by OJ Sumampouw (2015), namely Systematic, Continuous, Dynamic, Accommodative, Integrated and Focused and Simple and Realistic The method used is qualitative research methods and as informants consist of Regional Leaders of the Dikdasmen Council. Muhammadiyah Sinjai district, Principal of MTs Muhammadiyah Sinjai district, Staff and Teachers and Parents of Students and data collection techniques through observation, interviews, and documentation. Data analysis techniques include data reduction, data verification, and concluding. The results showed that teaching and learning activities were prevalent during the Corona pandemic, one of which was the Web course, which was the use of the internet for learning purposes, where all study materials, discussions, consultations, assignments, exercises, and exams were fully delivered via the internet and offline activities where teachers visited. students for the learning process due to lack of internet network access in several places in Sinjai Regency.
\end{abstract}

Keywords: Strategy, quality, education

\section{INTRODUCTION}

Currently, all countries in all parts of the world are being shocked by the outbreak of a disease caused by a virus called corona or better known as covid-19 (Coronavirus Diseases-19) which has changed the lifestyle of the Indonesian people. Moreover, since the social and physical distance appeal to the Large-Scale Social Restrictions (PSBB) has been implemented by the Government, significant changes have practically occurred. One of them that has been directly affected is the world of education. (Daniel, 2020; Mishra et al., 2020; Suprianto et al., 2020)

Education is a medium or tool to produce human resources into something of higher quality (Muslimin et al., 2020; Rachman et al., 2014.; Rakib et al., 2016). Quality human resources are needed in the current era. It is hoped that quality education can improve the ability, life, and dignity of the Indonesian nation (Baharuddin, 2018). Therefore, by maintaining and improving the quality of existing education, it is hoped that it will be able to produce human beings who are educated, have faith, have high character, are knowledgeable, have skills, and have a sense of responsibility. (Aslindawaty, 2017; Salam et al., 2016; Sukmawati et al., 2019).

The conditions that exist today are one of the causes of new problems that are present throughout the world, especially in the world of education, the learning process in schools is the 


\section{Jurnal Administrare: Jurnal Pemikiran Ilmiah dan Pendidikan Administrasi Perkantoran Volume 8 Number 1, January-June 2021. Pages 97-104}

best public policy tool as an effort to improve the quality of knowledge and skills (Abdullah et al., 2010; Deem \& Brehony, 2005; Henkel, 2018; Napirah et al., 2016). Also, many students think that school is a very fun activity, they can interact with each other. Schools can improve students' social skills and social class awareness. School as a whole is a medium for interaction between students and teachers to increase the ability of integrity, skills, and affection between them. But now the activity called school has stopped suddenly because of the Covid-19 interference.

During the Covid-19 Pandemic, Referring to the Press Statement of the Muhammadiyah Central Leadership Number: 002 / PER / I.0 / I / 2020 dated 05 Shawwal 1441 H to coincide with May 28, 2020 concerning Enforcement of the "New Normal", (1) Circular of the Muhammadiyah Central Executive Number: 005 / EDR / IE / 2020 dated 12 Syawal $1441 \mathrm{H}$ to coincide with June 4 regarding Guidelines and Guidelines for Facing the Pandemic and the Impact of Covid-19, (2) Circular of the Minister of Education and Culture Number 4 of 2020 concerning Learning from Home (BDR) and (3) The coordination meeting of the Basic and Secondary Education Council with MCCC, PP IPM on Saturday, March 30 2020, (4) Results of the meeting of the PP Muhammadiyah Primary and Secondary Education Council and the PP Muhammadiyah Islamic Boarding School Development Institute (LP2PPM), and MCCC on May 29, 2020 regarding the implementation of school education / Madrasah / Muhammadiyah Islamic boarding schools during the COVID-19 pandemic. By paying attention to the following matters, namely 1) Prioritizing mental safety (hifzhu an-nafs) and the health of students / santri, kiai, ustadz, teachers, civil servants, musyrif, and education personnel; 2) The spread and transmission of the COVID-19 outbreak has not shown a slowdown and a decline in 34 provinces in Indonesia; 3) The COVID-19 protocol requires Indonesian citizens to (a) maintain a safe distance (physical and social distancing) in interacting with one another; (b) stay away from the crowd, (c) wear a mask when outside the house; (d) always wash hands with soap and running water for at least 20 seconds; (e) wearing a hand sanitizer at a certain place or when entering the house; (f) prioritizing staying at home, etc .; 4) The interests and rights of stakeholders of Muhammadiyah Schools / Madrasahs / Pesantren, especially students / santri, and teachers / ustadz should not be harmed.

\section{METHOD}

The method in this research is descriptive qualitative. With a research focus, namely the strategy of the Primary and Secondary Education Council (DIKDASMEN) Muhammadiyah regional leaders in maintaining the quality of education in Sinjai Regency. Data collection techniques in this study, namely interviews, observation, and documentation. Sources of research data, namely primary and secondary data sources. As for the data analysis techniques in this study using data reduction techniques, data presentation, and concluding (Lexy J. Moleong, 2019). 


\section{RESULT AND DISCUSSION}

According to (1) Muhammadiyah Central Executive Press Statement Number: 002 / PER / I.0 / I / 2020 dated 05 Shawwal 1441 H to coincide with May 28, 2020, concerning Enforcement of the "New Normal", (2) Circular of Muhammadiyah Central Leadership Number: 005 / EDR / IE / 2020 dated 12 Syawal 1441 H to coincide with June 4 regarding Guidelines and Guidelines for Facing the Pandemic and the Impact of Covid-19, (3) Minister of Education and Culture Circular Number 4 of 2020 concerning Learning from Home and (4) Coordination Meetings Dikdasmen Assembly with MCCC, PP IPM on Saturday, March 30, 2020, (5) Results of the meeting of the PP Muhammadiyah Primary and Secondary Education Council and the PP Muhammadiyah Islamic Boarding School Development Institute, and MCCC on May 29, 2020, regarding the implementation of School / Madrasah / Muhammadiyah Islamic boarding schools during the COVID-19 pandemic.

Based on the results of research and analysis of research data that has been carried out on the Strategy of the Primary and Secondary Education Council (Dikdasmen) Muhammadiyah Regional Leaders in Maintaining the Quality of Education during the COVID-19 Pandemic in Sinjai Regency, it can be explained as follows:

\section{Continuous}

Various programs have a sustainable dimension so that they are carried out continuously and are interrelated. Even in the current pandemic era, which requires online learning to be carried out by utilizing technology, especially the internet. Online learning is carried out using a distance learning system, where Teaching and Learning Activities are not carried out face-toface. Learning is carried out using media, both print (module) and non-print (audio/video) media, computers/internet, radio, and television broadcasts.

It can be seen from several work programs carried out by the DIKDASMEN PD Council. Muhammadiyah Sinjai Regency in schools / madrasahs, among others:

\section{Table 1.1}

DIKDASMEN PD Assembly Work Program. Muhammadiyah Sinjai

\begin{tabular}{|c|c|c|c|}
\hline $\begin{array}{l}\text { Num } \\
\text { ber }\end{array}$ & Date and time & Description of activities & The place \\
\hline 1 & 06 June 2020 & $\begin{array}{l}\text { Publication of Quality Assurance } \\
\text { to All Madrasah Level Operators } \\
\text { through the ZoomMeeting } \\
\text { Application }\end{array}$ & IAIM Sinjai Campus Hall Room \\
\hline 2 & 10 June 2020 & $\begin{array}{l}\text { Publication on Learning Process } \\
\text { During MTs Level }\end{array}$ & $\begin{array}{l}\text { MTs Muhammadiyah Songing } \\
\text { (Sinjai South) }\end{array}$ \\
\hline 3 & 21 June 2020 & $\begin{array}{l}\text { Publication on Learning Process } \\
\text { During MA Level }\end{array}$ & $\begin{array}{l}\text { MA Muhammadiyah Teng'a } \\
\text { Lembang (West Sinjai) }\end{array}$ \\
\hline
\end{tabular}

Source: Secretary of DIKDASMEN PD. Muhammadiyah Sinjai in 2020 


\section{Systematic}

The program that is compiled is part of the concept of organizational implementation which is formulated in the form of an arrangement, method, and details that reflect comprehensive and sequential thinking. Teaching and learning activities or abbreviated as KBM which are widely applied during the Corona pandemic, one of which is the Web course, is the use of the internet for learning purposes, where all study materials, discussions, consultations, assignments, exercises, and exams are completely delivered via the internet. Students and teachers are completely separate, but the relationship or communication between students and teachers can be done at any time. Communication is mostly done asynchronously (online indirect) than synchronous (directly online).

A web course where some of the learning materials, discussions, consultations, assignments, and exercises are delivered through online media, but several stages such as exams and some consultations and some forms of discussion are carried out face-to-face, although in the learning process some are done face-to-face which is usually a tutorial. But face-to-face presentations are still smaller than online learning process presentations.

With this form, the center of learning activities shifts from classroom activities to activities through online media. students and teachers are completely separated but at the appointed time they meet face to face, either at school or in designated places. The application of this form is as carried out in schools/madrasas and Islamic boarding schools Muhammadiyah without reducing the rights of students/students to get educational services.

A web-enhanced course, namely the use of the internet for education, to support the improvement of the quality of learning activities in class. This form is also known as the web lite course because the main learning activity is face-to-face in class. The role of the internet here is to provide very rich content (learning resources) and also provide link facilities to various learning resources. Unlike the two previous forms, this web-enhanced course form of learning presentations via the internet is less than face-to-face learning presentations, because the use of the internet is only to support face-to-face learning activities. We hope and pray, that the Covid-19 pandemic will end soon, schools can re-enter, teaching and learning activities can be carried out normally so that the quality/quality of education can be achieved.

\section{Dynamic}

The program to be implemented has a high level of sensitivity to internal and external changes so that it can be implemented flexibly, following changes that occur in the environment. So far, the distance learning method is only limited to discussing theories and concepts, even though there are still very few who have practiced in learning, but with the Covid-19 pandemic, everything is forced to use online application media which is expected to run well while maintaining the process and the quality.

In the field of education, a major decision was taken to close schools from elementary, junior high schools, high schools, and universities and enforce online learning. The character of student learning before the Covid pandemic, elementary school students usually imitated the teacher's behavior that was immediately imitated by these students. for example, at Madrasah Tsanawiyah level students will start learning mathematics about a formula or theory in this subject. It is felt by teachers, that distance learning methods are sometimes less effective due to various factors, such as net ware (computer network components; reasons for weak signals), 
Dataware (data resource components; expensive internet package costs / especially felt by students), Brainware (human resource components; some teachers who lack information technology and computers), hardware (hardware components; computers and android/cellphones that lack support for application software; some students also do not have android/cell phones) and software (software components; application software used).

Realizing that ideal and effective learning, there must still be direct (face-to-face) interaction between the teacher and students in the class, but because the current situation is an emergency, the distance learning method is one of the solutions that can be done by the school, even in almost every situation. all countries learning in the classroom using online media. The school makes a scenario of teaching and learning activities for students to implement as the solution to all the existing obstacles, which in the real aspect means that learning activities must still be carried out and there is a process of interaction between teachers and students. The online aspect means that learning is connected through computer networks, the internet, and so on with online application media as a means used in learning. While the offline aspect is defined as being disconnected from the computer network, in this case, learning is carried out by still bringing students to school on a scheduled and periodic basis or vice versa, direct learning assignments and brought home, then students collect the assignments given by the teacher to school. Both of these are carried out at schools or madrasahs in the Sinjai district in implementing the learning process.

\section{Accommodating}

Program formulation and implementation is the result of the crystallization of the various aspirations, needs, and interests of the community in general. Some of the challenges that have been carried out and overcome by the Muhammadiyah Sinjai Regional Leadership Education Board and the school during this pandemic are in accordance with the implementation of health protocols and direct instructions from the Muhammadiyah central leadership regarding the implementation of Muhammadiyah school/madrasah / pesantren education that: 1) Schools must participate make efforts to prevent Covid-19 by implementing disciplined health protocols for all school members with the discipline of maintaining cleanliness and health, maintaining a safe distance, including implementing remote teaching and learning activities; 2) All schools continue to carry out the learning process with scenarios that have been set by each school; 3) The school must maintain good interaction and communication with students, parents, school committees, and the community or student families so that the existence of the school continues to receive support from these parties; 4) The school must continue to carry out professional school management, both curriculum management (especially the Covid-19 pandemic emergency curriculum), student management, infrastructure, educators and education personnel, and so on so that the quality and quality of the school can be maintained.

This web course form does not require face-to-face activities for both learning and evaluation and examination purposes, because all teaching and learning processes are fully carried out through the use of internet facilities. Also, this system is usually equipped with various digital learning resources, either self-developed or using various learning sources that are readily available on the internet; such as electronic libraries (e-libraries), e-books, and others.

To anticipate all the possibilities that may occur and may affect how the quality of education during the pandemic period is still ongoing, all related parties have carried out several 
102 Jurnal Administrare: Jurnal Pemikiran Ilmiah dan Pendidikan Administrasi Perkantoran

Volume 8 Number 1, January-June 2021. Pages 97-104

stages because seeing online learning, students can become less active in conveying their aspirations and thoughts so that it can lead to saturating learning.

\section{Integrated and Targeted}

The formulation and implementation of the program is a combination that is directed towards the realization of the goals. Online learning has several positive impacts on students because students can study anywhere and anytime. However, some problems can interfere with the online learning process, namely, students have less motivation to learn when carrying out online learning, even though the motivation to learn is an important thing in the learning process. Motivation in learning plays a role in fostering a sense of pleasure, passion, and enthusiasm for learning. Lack of motivation to learn in online learning is due to the online learning process, students can become less active in conveying their opinions and thoughts, causing a tedious learning process. If students experience boredom in learning, they will get progress in learning outcomes. Therefore, a driving force is needed to move students so that they are enthusiastic about learning so that they can have learning achievement.

\section{Simple and Realistic}

The formulation of program implementation is kept as simple as possible by considering the situations and conditions in which the program is run, as well as seeing the capabilities it has. The following are ways to achieve learning motivation, namely 1) Improving Teacher Quality to Improve Learning Quality. In the online learning process, the teacher is a determining factor for the success of online learning. The teacher is the dominant factor in determining the quality of learning. Learning that has good quality will produce good learning outcomes as well; 2) Choosing the Right Learning Method Teachers are required to be able to choose the right learning method for teaching. If the teacher can choose the appropriate learning method, the learning objectives will be achieved more easily. Selection of appropriate learning methods will also increase student motivation and interest in student learning so that a pleasant learning atmosphere will be created; 3) Maximizing Learning Facilities In the learning process, the use of good learning facilities also determines learning motivation in online learning process. Online learning requires facilities that support learning such as the internet, computers, or devices. The utilization of good facilities will maximize the material to be conveyed by maximizing the functions of existing facilities. The school is expected to provide optimal support to support online learning carried out by its teachers. such as the provision of learning resources, computers connected to the internet, and tools that support learning activities for teachers. These infrastructure facilities are used to seek knowledge and information from various sources; 4) Utilizing the Use of Media Student learning motivation in online learning can be increased by utilizing the use of attractive media so that it will make students interested in learning. In this case, the teacher can create or use animated media to support online learning. For example, teachers can create or use animated media to support the learning process, namely in the process of delivering abstract learning material, so that it can be easier to understand and more interesting. The animation media users can use attractive powerpoints, create attractive charts, make posters, or create video animations.

Conducting Learning Evaluation Evaluation on online learning is important to do. This is because by evaluating online learning it can be seen whether learning can run effectively or not. 
If it is deemed ineffective, it can make modifications to the learning system according to students.

\section{CONCLUSION}

The Board of Primary and Secondary Education Muhammadiyah Leadership in Sinjai Regency in terms of implementing strategies for maintaining the quality of education during the Covid-19 pandemic in Sinjai Regency during the current pandemic which demands online learning to be carried out by utilizing technology, especially the internet.Online learning is carried out using a distance learning system, where Teaching and Learning Activities are not carried out face-to-face. Learning is carried out using media, both print (module) and non-print (audio/video) media, computers / the internet. Teaching and learning activities or abbreviated as KBM which are widely applied during the Corona pandemic, one of which is the Web course, is the use of the internet for learning purposes, where all study materials, discussions, consultations, assignments, exercises, and exams are completely delivered via the internet. A web-enhanced course, namely the use of the internet for education, to support the improvement of the quality of learning activities in class. This form is also known as the web lite course because the main learning activity is face-to-face in class.

\section{REFERENCES}

Abdullah, F., Alani, F., Yaqoub, Y., Hamdan, M., Brady, M. K., Cronin, J. J. J., Cardona, M. M., Bravo, J. J., Caruana, A., Casidy, R., Chopra, A., Arora, U., Chowdhury, A. H., Miah, K., Dlačić, J., Arslanagić, M., Kadić-Maglajlić, S., Marković, S., Raspor, S., ... Parasuraman, A. (2010). A Study of Service Quality Determinants of Private Universities in Bangladesh using SERVQUAL. International Education Studies. https://doi.org/10.2307/1251929

Aslindawaty, N. (2017). Penerapan Model Pembelajaran Learning Cycle 5E (Engagment, Exploration, Explanation, Elboration, Evaluation) untuk Meningkatkan Hasil Belajar Ekonomi. Jurnal Office, 3(1), 19-24.

Baharuddin, B. (2018). PENGELOLAAN AKREDITASI MADRASAH MUHAMMADIYAH DALAM MENINGKATKAN MUTU PENDIDIKAN DI KECAMATAN SINJAI UTARA. Administrasita', 9(1), 28-41.

Daniel, S. J. (2020). Education and the COVID-19 pandemic. Prospects. https://doi.org/10.1007/s11125-020-09464-3

Deem, R., \& Brehony, K. J. (2005). Management as ideology: The case of "new managerialism" in higher education. Oxford Review of Education. https://doi.org/10.1080/03054980500117827

Henkel, M. (2018). Higher education. In Beyond Bureaucracy?: The Professions in the Contemporary Public Sector. https://doi.org/10.4324/9780429460678-10 
104 Jurnal Administrare: Jurnal Pemikiran Ilmiah dan Pendidikan Administrasi Perkantoran Volume 8 Number 1, January-June 2021. Pages 97-104

Lexy J. Moleong, D. M. A. (2019). Metodologi Penelitian Kualitatif (Edisi Revisi). PT. Remaja Rosda Karya. https://doi.org/10.1016/j.carbpol.2013.02.055

Mishra, L., Gupta, T., \& Shree, A. (2020). Online teaching-learning in higher education during lockdown period of COVID-19 pandemic. International Journal of Educational Research Open. https://doi.org/10.1016/j.ijedro.2020.100012

Muslimin, M., Saleh, S., \& Darwis, M. (2020). Implementation of the Use of Lecture Method in Filing Subjects at the Department of Office Vocational School YPLP PGRI 1 Makassar. Jurnal Ad'ministrare, 6(2), 95-104.

Napirah, M. R., Rahman, A., \& Tony, A. (2016). FAKTOR-FAKTOR YANG BERHUBUNGAN DENGAN PEMANFAATAN PELAYANAN KESEHATAN DI WILAYAH KERJA PUSKESMAS TAMBARANA KECAMATAN POSO PESISIR UTARA KABUPATEN POSO. Jurnal Pengembangan Kota. https://doi.org/10.14710/jpk.4.1.29-39

Rachman, E., Nawawi, J., Arismunandar, A. K., \& Akib, H. (2014). Autonomy of Private Higher Education Management: Financial Accountability Perspective.

Rakib, M., Rombe, A., \& Yunus, M. (2016). Pengaruh Pelatihan Dan Pengalaman Mengajar terhadap Profesionalitas Guru (Studi pada Guru IPS Terpadu yang Memiliki Latar Belakang Pendidikan dalam Bidang Pendidikan Ekonomi). Jurnal Ad'ministrare" Jurnal Pemikiran Ilmiah Dan Pendidikan Administrasi Perkantoran", 3(2), 1-148.

Salam, R., Zunaira, Z., \& Niswaty, R. (2016). Meningkatkan Hasil Belajar Membuat Dokumen melalui Penggunaan Model Pembelajaran Kooperatif Tipe Make a Match (Mencari Pasangan). Jurnal Office, 2(2), 173-180.

Sukmawati, S., Jamaluddin, J., Niswaty, R., \& Asmanurhidayani, A. (2019). The Influence of Headmaster Leadership Style on Teacher Performance. Jurnal Office, 4(2), 91-102.

Suprianto, S., Arhas, S. H., \& Mahmuddin, M. (2020). The Effectiveness of Online Learning Amid the COVID-19 Pandemic. Jurnal Ad'ministrare, 7(2), 321-330. 